\title{
Causality between Government Expenditure and Government Revenue in Nigeria
}

\author{
Balogun Abdulrasheed ${ }^{1}$ \\ 'Department of Economic Planning, Research \& Statistics Federal Capital Territory Administration, Abuja, \\ FCT Nigeria
}

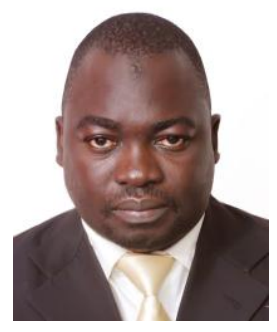

\begin{abstract}
This study seeks to establish the causality between government expenditure and government revenue in Nigeria. The type of research adopted is ex post-facto and the updated annual time series data between 1986-2015 were obtained through Statistical data bulletins and annual reports of Central Bank of Nigeria in order to evaluate the variables such as total revenue and aggregate public expenditure of the federal government. The study applied co-integration statistical method and vector autoregressive techniques comprising an Error Correction Model (ECM) and Augmented Dickey Fuller as the methods of analyses. The findings showed that there is spendrevenue practice in Nigeria in line with the theory of Barro (1974); Peacock and Wiseman. (1979) indicating that changes in government expenditure triggered changes in government revenue. The Co-integration tests also revealed that there is existence of long run equilibrium relationships between government revenue and expenditure variables. The outcome of this study showed that increase in government expenditure without a simultaneous increase in revenue could broaden the budget deficit.
\end{abstract}

Keywords: Public revenue, Public expenditure, Fiscal administration.

Citation | Balogun Abdulrasheed (2017). Causality between Government Expenditure and Government Revenue in Nigeria. Asian Journal of Economics and Empirical Research, 4(2): 90-98. History:

Received: 10 May 2017

Revised: 19 June 2017

Accepted. 3 October 2017

Published: 24 October 2017

Licensed: This work is licensed under a Creative Commons

Attribution 3.0 License $(\mathrm{coc}) \mathbf{E}$

Publisher:Asian Online Journal Publishing Group

\section{Contents}

1. Introduction

Funding: This study received no specific financial support.

Competing Interests: The author declares that there are no conflicts of interests regarding the publication of this paper.

Transparency: The author confirms that the manuscript is an honest, accurate, and transparent account of the study was reported; that no vital features of the study have been omitted; and that any discrepancies from the study as planned have been explained.

Ethical: This study follows all ethical practices during writing.

2. Methodology

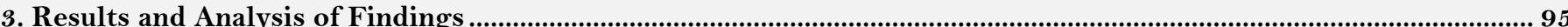

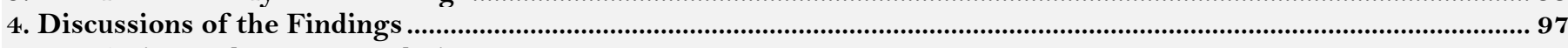

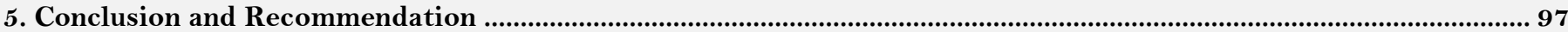

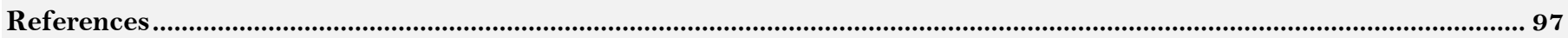




\section{Introduction}

Oil revenue has remained the major source of revenue to Nigeria over decades, over reliance on oil has therefore crippled other potential sources of revenue. The recent dwindling in oil revenue due to series of factors such as vandalisation, oil theft, mismanagement, non-remittance, connivance and general corrupt practices etc has open up avenue for other non-oil sector to be explored, which includes taxes, customs duty and tariff, fees, penalties among others.

Government Expenditure and revenue have over the years remained significant and critical interplay variables in fiscal administration. The government in Nigeria takes transparency and accountability in treasury management very seriously. The implementation of a treasury single account to receive revenues and monitor financial flows at the centre, high level probe of government contracts and physical and forensic accreditation of staff to detect ghost workers are key ways that show that new government in Nigeria is determined to ensure efficiency and effectiveness in financial and economic management (Fakile, Adegbie and Faboyede 2014).

Improving fiscal strategy is inevitable to mobilize needed resources for socio-economic development but that can only be achievable with efficient methods with significant development progress in infrastructure, social services and job creation. Although this may be controversial, reducing or removing fuel subsidies is also a viable way to raise revenue.

Drummond, Daal, Srivastava and Oliveira (2012) argued that given the limited resources available for implementation of the vast infrastructure required in some African countries, mobilizing more income and improving on the economic reconstruction is a priority for them. These countries have huge improvement plan to execute, but weak revenue drive is the genesis of fiscal disparity that these countries in the region experience.

Nwogwugwu and Okoronkwo (2015) also posited that Governments at different levels have the responsibility of mobilizing revenue to meet the requirements of the public by providing infrastructural needs and making sure that the well-being of the people are guaranteed. Most states in Nigeria encountered serious issues concerning people's level of tax obligation fulfillment which sometimes result to their unjustifiable reliance on constitutional sharing of federation account.

Fakile et al. (2014) Agree that despite the opportunity for domestic resource mobilization, the need for foreign aid and private sector investments cannot be overemphasized. The best results for economic management can only be achieved in an atmosphere where the due process of law is respected; improved security system is guarantee and investment environment good for investors is assured. Improving fiscal strategy and efficient financial and economic management system will provide needed resource climate for sustainable development of the country.

Therefore considering the causality between the government expenditure and revenue, there is the need to analyse the type of relationship and the shape of the direction that exist between them in Nigeria as was done in several other countries.

Mainoma and Aruwa (2015) in their most recent study and several other past literatures that were reviewed such as Von Furstenberg et al. (1986); Anderson et al. (1986); Nwogwugwu and Okoronkwo (2015); Mohsen and Abbas (2014); Al-Zeaud (2015); Saeed and Somaye (2012); Mohsen et al. (2011); Li (2001); Fasano and Wang (2002); Al-Qudair (2005) and Nwosu and Okafor (2014) have conducted studies to establish the relationship between government revenues and government expenditure.

The study of Mainoma and Aruwa (2015) therefore, using time series data covering a period of 30years between 1979-2008, employed the impulse response functions and Vector Autoregressive(VAR) model for the purpose of analysis discovered that causality runs from Revenue to Public expenditure by supporting Revenuespend hypothesis and aligning with Blackley (1986) and Ram (1988).

But this study failed to capture the effect of growth in government expenditure and revenue that translated to recent positive economic growth that catapulted Nigeria to become the biggest economy in Africa after rebasing in 2013. In order to investigate this position, we intend to update and extend this study to 2015 to capture this effect. The study however uses time series data covering 30years period between 1986 and 2015 .

Therefore, the objective of this study is to determine the causal relationship between aggregate government revenue and aggregate government spending in Nigeria. The following hypothesis will be answered;

$\mathrm{H}_{\mathrm{O}} \quad$ There is no significant causality between government revenue and government expenditure in Nigeria.

$\mathrm{H}_{1}$ There is significant causality between government revenue and government expenditure in Nigeria.

\subsection{Conceptual Issues}

There are different hypotheses regarding the relationship between government revenue and expenditure. First hypothesis was proposed by Buchanan and Wagner (1977) and Friedman (1978) which holds that government revenues solely determined its expenditure which indicates a unidirectional causality that runs from revenues to expenditure. According to Friedman, high taxes imply more spending leading to a larger budget deficit at the end. In the case of Nigeria, government expenditure is financed mostly through oil exports revenues that accounted for about $80 \%$ of total government revenues and non-oil revenue accounted for $20 \%$. Second hypothesis was proposed by Barro (1974); Peacock and Wiseman. (1979) holds that government determines its expenditure prior to its revenues which is regarded as spend and tax hypothesis. Peacock and Wiseman argues that during crises, government increases its expenditure which; eventually, lead to higher taxes. Hence, there is a unidirectional causality runs from government expenditure to revenues. In the case of Nigeria, the policy makers consider the expected government expenditure when they determine the optimal level of government revenues (Nwosu and Okafor, 2014); (Anderson et al., 1986). Third view argued by Musgrave (1966) and Meltzer and Richard (1981) who posited that government makes simultaneously its revenues and expenditure which means that there is a bidirectional relationship between government revenues and expenditure. This hypothesis, the fiscal synchronization hypothesis or the fiscal neutrality hypothesis indicates bidirectional relationship between revenue and spending. If the bidirectional causality between public revenue and public expenditure does not hold, it means that public expenditure decisions are made free of public revenue decisions and vice versa (Darrat, 1998); (Von Furstenberg et al., 1986); (Chang et al., 2002). Finally, Baghestani and McNown (1994) are of the view that none of the above hypotheses illustrate the relationship between public revenues and expenditure. Government expenditure and 
revenues are separately determined by the long run economic development showing the institutional separation between public revenues and expenditure. This final hypothesis is the institutional separation hypothesis where separate decisions on revenue are decided independent of allocations on government expenditure, and therefore no causal relationship between revenue and spending is expected (Al-Qudair, 2005).

\subsection{Empirical Literature Review}

Different empirical studies in this area of study have revealed as follows; Hasan and Lincoln (1997) carried out a research on this issue for United Kingdom by using co integration technique and they used quarterly data from 1961-93 for this purpose, the outcome showed that government tax revenue Granger causes government expenditures.

Owoye (1995) examined the G7 countries and discovered bidirectional relationship in five of the seven countries while in Japan and Italy he discovered causality running from revenue to expenditure. Kollias and Makrydakis (2000) discovered tax and spending relationship in four countries namely; Greece, Portugal, Spain, Ireland which are comparatively poorer countries in European Union. They found that co integration prevails in only Greece and Ireland whereas there is no long run relationship in the models for Spain and Portugal. Chang et al. (2002) conducted a study to examine this relationship in ten industrialized countries including three newly industrialized Asian economies namely, Taiwan, South Korea and Thailand. In this study, GDP variable is also included in the model as a control variable along with government expenditures and tax variables and Johansen cointegration technique is exercised for analysis. They claimed that co integration among the variables prevails for seven countries and found causality from government revenues to government expenditures for UK, USA, South Korea, Japan and Taiwan while causality runs from government expenditures to revenues for South Africa and Australia. This study also found independence between revenues and expenditures for New Zealand and Thailand.

Fasano and Wang (2002) investigated this relationship for oil-dependent GCC countries and found evidence of unidirectional causality running from revenue to expenditure in Bahrain, the United Arab Emirates and Oman while they found bidirectional causality for Kuwait, Qatar and Saudi Arabia. They advise that the GCC countries could improve the effectiveness of their fiscal procedure by allowing budget expenditure to be less driven by revenue availability. $\mathrm{Li}$ (2001) by applying the co integration and error correction models over the period 19501997 for China found bidirectional causality between government expenditure and revenue.

In another study, Narayan and Narayan (2006) found tax-and-spend hypothesis for Mauritius, El Salvador, Chile, Paraguay and Venezuela. For Haiti, fiscal synchronization hypothesis was discovered, while in, while in Peru, South Africa, Guatemala, Guyana, Uruguay and Ecuador there is evidence of neutrality by application of the Toda and Yamamoto (1995) test for Granger causality.

Craigwell et al. (1994) examined government revenue and expenditure causality in the presence of seasonality in Barbados. Applying seasonal unit roots, co-integration test, Granger causality and vector error correction methodologies, their results established that the variables are significantly co-integrated, and that a unidirectional causality from government revenue to total government expenditure exists. The outcome further revealed that bivariate and multivariate techniques showed a proof of a unidirectional movement from revenue to spending. AlQudair (2005) examined the relationship between public expenditure and revenues in Saudi Arabia applying co integration technique, Error Correction Model (ECM) and Granger causality test. The co integration test showed the presence of long run equilibrium between public expenditure and revenues.

In Pakistan Ali and Shah (2012) who examined government revenue and expenditure mix using yearly data for the period 1976-2009. They applied the Johansen co-integration and Granger causality techniques and discovered no relationship in the variables both in the long run and the short run granger. This result supports institutional separation hypothesis.

In Nigeria, the following studies were conducted to examine the causal-relationship between government expenditure and government revenue, Mainoma and Aruwa (2015) using Vector Error Correction Model based causality test for the periods 1979 to 2008. Their findings showed that causality runs from revenue to public expenditure in Nigeria, their causality test and impulse response analysis confirm that government revenue has a significant impact on public expenditure in Nigeria. Also, Aregbeyen and Taofik (2012) also investigated the long run relationships and dynamic interactions between the government revenues and expenditures in Nigeria over the period 1970 to 2008. Using Autoregressive Distributed Lag experiment, the outcome showed that there is a long run relationship between public expenditures and revenues, and no evidence of a long run relationship was found. Therefore, the tax- spend hypothesis was established. Emelogu and Uche (2010) also conducted a study in Nigeria to investigate the relationship between public revenue and government expenditure. They used yearly data from 1970 to 2007 . They also applied the Engel-Granger co-integration technique, the Johansen co-integration method and the Granger causality test within the Error Correction Modeling (ECM) framework and discovered a long-run relationship between the two variables and a unidirectional causality running from public revenue to expenditure in Nigeria, Ogujiuba and Abraham (2012) also examined the revenue-spending hypothesis for Nigeria using largescale data from 1970 to 2011 . They applied correlation analysis, granger causality test, regression analysis, lag regression model, vector error correction model and impulse response analysis, they report that revenue and expenditure are linked and that causality runs from revenue to expenditure in Nigeria. The vector error correction model also proves that there is a considerable long run relationship between revenue and expenditure and finally, Nwosu and Okafor (2014) examined the relationship between both total expenditure and total revenue in Nigeria using yearly data from 1970 to 2011. Their study employed co-integration techniques and Vector Autoregressive (VAR) models with an Error Correction term as the methods of analyses. The Co-integration tests showed the presence of long run equilibrium relationships between government revenue and expenditure variables. The VAR results also show that total government expenditure, capital and recurrent expenditures have long run unidirectional relationships with total revenue, as well as unidirectional hypothesis running from expenditure to revenue.The outcome aligned with the spend-tax hypothesis in Nigeria implying that changes in government expenditure bring about changes in government revenue. 


\subsection{The Theory of Public Expenditure}

Public expenditure refers to the expenses which Government incurs in the performance of its operations. With increasing State responsibilities to citizens, it may be difficult to evaluate what portion of public expenditure can be attributed to the maintenance of Government itself and what portion to the advantage of the society and the economy in general. In spite of the fact that public expenditure has increased rapidly over the years, and despite of its growing responsibility and significance in the national economy, the area of public expenditure becomes relatively unexplored. Studies have generally been concentrated on taxation and the effects of public expenditure on employment and prices. Two notable theories of public expenditure are examined, namely:

\section{(i) The Law of Increasing State Activities}

A German Economist- Adolph Wagner in 1890 postulated this theory. According to him, there are intrinsic inclinations for the activities of Government to grow, both intensively and extensively. He added that there exists a functional relationship between the growth of an economy and that of Government activities, and that the Governmental sector develops faster than the economy. All categories of Governments, irrespective of their levels, intentions and sizes, had exhibited similar tendencies of increased expenditure (Wagner, 1890). Keynes (1936) on the other hand, raise the idea that during economic downturn the use of fiscal policies boosts economic activities i.e expansionary fiscal policies, expanding public expenditures, increase economic growth (Mainoma and Aruwa, 2015); (Buchanan and Wagner, 1978).

\section{(ii) The Displacement Theory}

Peacock and Wiseman (1961) put forth the theory that public expenditure does not increase in a straight or continuous manner, but in "Jack or Stepwise" fashion. At times, some social or other disturbances occur which show the need for increase in public expenditure, which the current level of revenue cannot meet. Therefore, public expenditure increases will make the failure of the current level of revenue clear to everyone. The movement from the initial and insufficient level of expenditure and taxation to a new and greater level is known as the "displacement effect," while the insufficiency of the revenue as compared with the required expenditure creates the "inspection effect." Both Government and the people would attain a new level of "tax tolerance" by reviewing the revenue position and finding solution to the problem of inadequate finance. Since each major disturbance will compel Government to assume a larger proportion of the national economic activities, the outcome is the 'concentration effect'. Therefore, 'concentration effect' is the tendency for Government activities to grow faster than the economy.

\section{Methodology}

This study follows the Fasano and Wang (2002) method by utilizing co-integration and error correction term modeling framework; we also adopt the normal Vector Error Correction Model Based granger causality method and Augmented Dickey Fuller. The work also updates the data used in Nigeria by Mainoma and Aruwa (2015) and Nwosu and Okafor (2014). Annual data for the period from $1986-2015$ are used in this study. These data are obtained from the Central Bank of Nigeria (CBN) Statistical Bulletin, and were transformed to logarithms to eliminate the problem of heteroskedasticity. We select these period because time series data on government revenue and government expenditure are only available for this period (Central Bank of Nigeria, 2015).

The relationships between government revenues and expenditures are specified empirically below:

$$
\begin{aligned}
& \text { TOTEXP }=\beta_{0}+\beta_{1} \text { TOTEXP }_{\mathrm{t}-1}+\beta_{2} \text { TOREV }+\boldsymbol{\varepsilon}_{1} \ldots \ldots \ldots \ldots \ldots \ldots \ldots \ldots . . . \ldots(1) \mathrm{A} \\
& \text { TOREV }=\beta_{0}+\beta_{1} \text { TOREV }_{\mathrm{t}-1}+\beta_{2} \text { TOTEXP }+\boldsymbol{E}_{1} \ldots \ldots \ldots \ldots \ldots \ldots \ldots \ldots \ldots(1) \mathrm{B}
\end{aligned}
$$

The variables are as defined above. The constant terms are represented by $\beta_{0}$ s as the coefficients to be estimated and $\Sigma_{1}$ are the stochastic error terms with all the standard attributes. A priori, we expect the independent variable in all the equations to be positively signed, i.e.

$\mathrm{B} 1>\mathrm{O}$

\section{Time Series Properties of the Variables}

\section{(a) Unit Root Tests}

We determine the stationarity properties of the variables using test of unit roots of the Augmented DickeyFuller (ADF) Test. While the ADF procedure is likely to be the most frequently used test, it does not however requires homoscedastic and uncorrelated errors in the underlying arrangement (Akaike, 1969);(Dickey and Fuller, 1979);(Dickey and Fuller, 1981);(Perron, 1989);(Phillips and Perron, 1988).

\section{(b) Co-Integration Tests}

To test for co-integration, the Johansen maximum-likelihood approach was used. It is necessary to find out if the two series are co- integrated. Two or more variables will co-integrate if they are bounded by a common trend. Furthermore, the series are tied by some long run equilibrium relationship and in the short-run they may deviate but at the end, they will still exhibit the same stochastic trend. The Johansen-Juselius also provides likelihood ratio statistics with exactly known distributions. If the variables are co-integrated, the last stage of the Time-Series analysis is to construct dynamic error correction models (ECMs) that considers the underlying co-integration properties. The ECM differs from the standard Granger-Causality models in equations because they add another regressor in each equation namely, the estimated residuals (the error correction, EC, terms) obtained from the associated co-integrating equations(Johansen, 1988);(Johansen and Juselius, 1990);(Miller and Russek, 1990).

\section{(c) Error Correction Model and Granger Causality}

After the co-integration model of the variables is determined, an Error Correction Model (ECM) can then be estimated. The error-correction model arises from the long-run co-integration relationship. The error correction 
term (ECM) will then be used to check for the speed of adjustment of the model from the short run to the long run equilibrium. The greater the coefficient of the error correction term, the faster the speed of adjustment of the model from the short run to the long run(Engle and Granger, 1987);(Granger, 1969);(Granger, 1988);(Granger and Newbold, 1974).

Table-1. Aggregate Public Revenue and Expenditure in Nigeria from 1986-2015

\begin{tabular}{|c|c|c|c|c|}
\hline \multirow{2}{*}{ YEAR } & \multicolumn{2}{|c|}{ Aggregate Public Expenditure (N' BILLION) } & \multicolumn{2}{|c|}{ Total Revenue(TOREV) } \\
\hline & PEXP & LNPEXP & REV & LNREV \\
\hline 1986 & 16.22 & 2.79 & 12.60 & 2.53 \\
\hline 1987 & 22.02 & 3.09 & 25.38 & 3.23 \\
\hline 1988 & 27.75 & 3.32 & 27.60 & 3.32 \\
\hline 1989 & 41.03 & 3.71 & 53.87 & 3.99 \\
\hline 1990 & 60.27 & 4.10 & 98.10 & 4.59 \\
\hline 1991 & 66.58 & 4.20 & 100.99 & 4.62 \\
\hline 1992 & 92.80 & 4.53 & 190.45 & 5.25 \\
\hline 1993 & 191.23 & 5.25 & 192.77 & 5.26 \\
\hline 1994 & 160.89 & 5.08 & 201.91 & 5.31 \\
\hline 1995 & 248.77 & 5.52 & 459.99 & 6.13 \\
\hline 1996 & 337.22 & 5.82 & 523.60 & 6.26 \\
\hline 1997 & 428.22 & 6.06 & 582.81 & 6.37 \\
\hline 1998 & 487.11 & 6.19 & 463.61 & 6.14 \\
\hline 1999 & 947.69 & 6.85 & 949.19 & 6.86 \\
\hline 2000 & 701.06 & 6.55 & 1906.16 & 7.55 \\
\hline 2001 & 1018.03 & 6.93 & 2231.60 & 7.71 \\
\hline 2002 & 1018.16 & 6.93 & 1731.84 & 7.46 \\
\hline 2003 & 1225.97 & 7.11 & 2575.10 & 7.85 \\
\hline 2004 & 1426.20 & 7.26 & 3920.50 & 8.27 \\
\hline 2005 & 1822.10 & 7.51 & 5547.50 & 8.62 \\
\hline 2006 & 1938.00 & 7.57 & 5965.10 & 8.69 \\
\hline 2007 & 2450.90 & 7.80 & 5727.50 & 8.65 \\
\hline 2008 & 3240.82 & 8.08 & 7866.59 & 8.97 \\
\hline 2009 & 3452.99 & 8.15 & 4844.59 & 8.49 \\
\hline 2010 & 4194.58 & 8.34 & 7303.67 & 8.90 \\
\hline 2011 & 4712.06 & 8.46 & 11116.90 & 9.32 \\
\hline 2012 & 4605.39 & 8.43 & 10654.75 & 9.27 \\
\hline 2013 & 5185.32 & 8.55 & 9759.79 & 9.19 \\
\hline 2014 & 4587.39 & 8.43 & 10068.85 & 9.22 \\
\hline 2015 & 4988.86 & 8.51 & 6912.50 & 8.84 \\
\hline
\end{tabular}

\section{Results and Analysis of Findings}

Table-2.Aggregate public expenditure unit root test at level

\begin{tabular}{|c|c|c|c|c|}
\hline ADF Test Statistic & -4.043958 & \multicolumn{2}{|c|}{$1 \%$ Critical Value* } & -3.6852 \\
\hline & & \multicolumn{2}{|c|}{$5 \%$ Critical Value } & -2.9705 \\
\hline & & \multicolumn{2}{|c|}{$10 \%$ Critical Value } & -2.6242 \\
\hline \multicolumn{5}{|c|}{ *MacKinnon critical values for rejection of hypothesis of a unit root. } \\
\hline \multicolumn{5}{|c|}{ Augmented Dickey-Fuller Test Equation } \\
\hline \multicolumn{5}{|c|}{ Dependent Variable: D(LNPEXP) } \\
\hline \multicolumn{5}{|c|}{ Method: Least Squares } \\
\hline \multicolumn{5}{|c|}{ Date: 09/04/16 Time: 22:37 } \\
\hline \multicolumn{5}{|c|}{ Sample(adjusted): 19882015} \\
\hline \multicolumn{5}{|c|}{ Included observations: 28 after adjusting endpoints } \\
\hline Variable & Coefficient & Std. Error & t-Statistic & Prob. \\
\hline $\operatorname{LNPEXP}(-1)$ & -0.081350 & 0.020116 & -4.043958 & 0.0004 \\
\hline $\mathrm{D}(\mathrm{LNPEXP}(-1))$ & -0.556256 & 0.153807 & -3.616594 & 0.0013 \\
\hline $\mathrm{C}$ & 0.828314 & 0.145862 & 5.678770 & 0.0000 \\
\hline R-squared & 0.471346 & \multicolumn{2}{|c|}{ Mean dependent var } & 0.193681 \\
\hline Adjusted R-squared & 0.429054 & \multicolumn{2}{|c|}{ S.D. dependent var } & 0.223790 \\
\hline S.E. of regression & 0.169098 & \multicolumn{2}{|c|}{ Akaike info criterion } & -0.615721 \\
\hline Sum squared resid & 0.714853 & \multicolumn{2}{|c|}{ Schwarz criterion } & -0.472985 \\
\hline Log likelihood & 11.62009 & \multicolumn{2}{|c|}{ F-statistic } & 11.14496 \\
\hline Durbin-Watson stat & 2.323330 & \multicolumn{2}{|c|}{ Prob(F-statistic) } & 0.000346 \\
\hline
\end{tabular}


Table-3.Total revenue (torev) unit root test at level

\begin{tabular}{|c|c|c|c|c|}
\hline \multirow[t]{3}{*}{ ADF Test Statistic } & -2.537597 & \multicolumn{2}{|c|}{$1 \%$ Critical Value* } & -3.6852 \\
\hline & & \multicolumn{2}{|c|}{$5 \%$ Critical Value } & -2.9705 \\
\hline & & \multicolumn{2}{|c|}{$10 \%$ Critical Value } & -2.6242 \\
\hline \multicolumn{5}{|c|}{ *MacKinnon critical values for rejection of hypothesis of a unit root. } \\
\hline \multicolumn{5}{|c|}{ Augmented Dickey-Fuller Test Equation } \\
\hline \multicolumn{5}{|c|}{ Dependent Variable: D(LNREV) } \\
\hline \multicolumn{5}{|c|}{ Method: Least Squares } \\
\hline \multicolumn{5}{|c|}{ Date: 09/04/16 Time: $22: 42$} \\
\hline \multicolumn{5}{|c|}{ Sample(adjusted): 19882015} \\
\hline \multicolumn{5}{|c|}{ Included observations: 28 after adjusting endpoints } \\
\hline Variable & Coefficient & Std. Error & t-Statistic & Prob. \\
\hline LNREV(-1) & -0.084179 & 0.033173 & -2.537597 & 0.0178 \\
\hline $\mathrm{D}(\operatorname{LNREV}(-1))$ & -0.208888 & 0.189143 & -1.104390 & 0.2799 \\
\hline $\mathrm{C}$ & 0.837787 & 0.255462 & 3.279501 & 0.0031 \\
\hline R-squared & 0.208869 & \multicolumn{2}{|c|}{ Mean dependent var } & 0.200254 \\
\hline Adjusted R-squared & 0.145578 & \multicolumn{2}{|c|}{ S.D. dependent var } & 0.346295 \\
\hline S.E. of regression & 0.320098 & \multicolumn{2}{|c|}{ Akaike info criterion } & 0.660575 \\
\hline Sum squared resid & 2.561561 & \multicolumn{2}{|c|}{ Schwarz criterion } & 0.803311 \\
\hline Log likelihood & -6.248054 & \multicolumn{2}{|c|}{ F-statistic } & 3.300162 \\
\hline Durbin-Watson stat & 1.999060 & \multicolumn{2}{|c|}{ Prob(F-statistic) } & 0.053469 \\
\hline
\end{tabular}

Table $2-3$ above show the ADF test results of the time series. The results revealed that the null hypothesis (Ho) of unit root test can be rejected at level for public expenditure and public revenue showing that the test is significant at 1\%,5\% and 10\% significant level, the p-value is less than 0.05 level of significance and all the variables (i.e LNPEXP, LNREV) are therefore stationary at the level. ADF statistics are obtained by taking Akaike Information Criterion (AIC) into consideration, lagged differences are shown table by table and the levels of significance are shown at $1 \%, 5 \%$, and $10 \%$. The tables above also showed the performance of the model $R 2$, the adjusted $R 2$, the standard error of estimate and durbin-watson $R$. Table 2 show $R 2$, the performance of the model $=0.471$ and this shows that $47.1 \%$ percentages of the variation in the dependent variable (public expenditure) are accounted for by the independent variable (public Revenue) while the remaining $52.9 \%$ will be due to other factors unknown. The adjusted $R 2$ shows that when the effect of increase in the number of observations for the variables is removed, the amount of variation that will be accounted for will be $42.9 \%$. While Durbin-Watson statistic indicates that there is no serial correlation. As a rule of thumb a value of 2 indicates the absence of auto correlation. However results from the Durbin-Watson table also confirms the absence of serial correlation. Since the all variables are clearly stationary in Table 2 and 3, the variables of each version of Wagner's law can be integrated of order one.

a. Predictors: (Constant), LNREV

b. Dependent Variable: LNEXP

The test hypothesis is given as

$$
\text { Ho: } R 2=0 \text { VS } H 1: R 2=1
$$

The decision rule is to reject $H$ o if p-value (Sig) is less than 0.05 level of significance, otherwise we accept. Hence, since the $\mathrm{P}$-value $(\mathrm{Sig})=0.00$ is less than 0.05 , we reject $\mathrm{HO}$ and conclude that there is a significant relationship between the dependent variable (Government expenditure) and independent variable (Government revenue).For F- Test statistics, the decision rule is that reject Ho if F-calculated is greater than F-tabulated, if otherwise, accept. Therefore comparing the figure from the table, the $\mathrm{F}$ - calculated is greater than the $\mathrm{F}$ - tabulated at all levels of difference for both LNREV and LNEXP, hence we reject the Ho and conclude that there is significant relationship between the dependent variable and the independent variable. The model is well formulated.

Date: 09/04/16 Time: 22:47

Table-4. Johansen cointegration test

Sample: 19862015

Included observations: 28

Test assumption: Linear deterministic trend in the data

Series: LNPEXP LNREV

Lags interval: 1 to 1

\begin{tabular}{|c|c|c|c|c|}
\hline & Likelihood & 5 Percent & 1 Percent & Hypothesized \\
\hline Eigenvalue & Ratio & Critical Value & Critical Value & No. of $\mathrm{CE}(\mathrm{s})$ \\
\hline 0.428242 & 25.46338 & 15.41 & 20.04 & None ${ }^{*} *$ \\
\hline 0.295570 & 9.810249 & 3.76 & 6.65 & At most 1 *** \\
\hline \multicolumn{5}{|c|}{$\left.*^{* *}\right)$ denotes rejection of the hypothesis at $5 \%(1 \%)$ significance level } \\
\hline \multicolumn{5}{|c|}{ L.R. test indicates 2 cointegrating equation(s) at $5 \%$ significance level } \\
\hline \multicolumn{5}{|c|}{ UnnormalizedCointegrating Coefficients: } \\
\hline LNPEXP & LNREV & & & \\
\hline-0.002498 & 0.110451 & & & \\
\hline-0.932075 & 0.810425 & & & \\
\hline \multicolumn{5}{|c|}{ Normalized Cointegrating Coefficients: 1 Cointegrating Equation(s) } \\
\hline LNPEXP & LNREV & $\mathrm{C}$ & & \\
\hline \multirow[t]{2}{*}{1.000000} & -44.22331 & 302.3088 & & \\
\hline & $(3532.98)$ & & & \\
\hline Log likelihood & 5.297447 & & & \\
\hline
\end{tabular}

Source: Output from Eviews Econometric software 4.0(2009)

The results of co-integration analysis are presented in Table 1.3 above. The co-integration test results suggest that the null-hypothesis of no co-integration between public expenditure and public revenue is rejected. Since the variables are stationary, integrated of order one, and co-integrated. 
Table-5.Vector error correction model - based causality

Pairwise Granger Causality Tests

Date: 09/04/16 Time: 22:49

Sample: 19862015

Lags: 2

\begin{tabular}{l|l|l|l}
\hline Null Hypothesis: & Obs & F-Statistic & Probability \\
\hline LNREV does not Granger Cause LNPEXP & 28 & 0.42234 & 0.66049 \\
\hline LNPEXP does not Granger Cause LNREV & 2.91095 & 0.04465 \\
\hline Source: Ount from Eiens Ecotric
\end{tabular}

Source: Output from Eviews Econometric software 4.0(2009)

Table 5presents the direction of causality between public expenditure and public revenue as investigated using Vector Error Correction Model (VECM) causality test. The VEC Model results confirm that causality runs from government expenditure to public revenue for the sampled periods 1986-2015 in Nigeria. The causality test analysis confirms that government expenditure has a significant impact on public revenue in Nigeria.

ECT is consider good if the range between $0 \sim 1$ but not more than 2 . ECT should be in negative number and if positive value means explosive and not reasonable. For example, if the ECT $(-1)$ estimated coefficient is -0.87 (The estimated coefficient indicates that about 87 per cent of this disequilibrium is corrected between 1 year (if annually data). But if the ECT $(-1)$ are -1.07 as an example (The estimated coefficient indicates that about 107 per cent of this disequilibrium is corrected between 1 year - and this does not make sense).

\section{Discussions of the Findings}

Based on the above results, the causality runs from public expenditure to revenue in Nigeria. This finding rejects Revenue-Spend hypothesis of Buchanan and Wagner (1977) and Friedman (1978) but agrees with the spend-tax hypothesis of Barro (1974); Peacock and Wiseman. (1979) supported by findings of Nwosu and Okafor (2014); Von Furstenberg et al. (1986); Anderson et al. (1986); Islam (2001); Fasano and Wang (2002). This result is therefore at variance with the results of Mainoma and Aruwa (2015); Blackley (1986); Ram (1988); Emelogu and Uche (2010); Narayan and Narayan (2006) and Aregbeyen and Taofik (2012). The study revealed that the levels of revenue and expenditure are co-integrated i.e. they move on a common trend as long as temporal budget constraint is binding over the long run, therefore the co-integration showed a long run relationship between expenditure and revenue. Also, each time series in the study are first tested for their orders of integration by using Augmented Dickey-Fuller (ADF) test. The result shows that expenditure and revenue are integrated of order one or $1(1)$ and are also significant at all levels i.e $1 \%, 5 \%$, and $10 \%$.

\section{Conclusion and Recommendation}

This paper deals with the concept of causality between government expenditure and revenue in Nigeria, using time series data from 1986 to 2015. The study adopted a VAR model which included Vector Error Correction Model (ECM) as the method of analysis. The results from the analyses show that expenditure has long run unidirectional relationships of Spend-Tax between government revenue and public expenditure in Nigeria. This causality runs from expenditures to revenue. This however confirm the Spend-Tax hypothesis of Peacock and Wiseman. (1979) and agrees with the studies of Nwosu and Okafor (2014); Von Furstenberg et al. (1986); Anderson et al. (1986); Islam (2001); Fasano and Wang (2002). The policy implication derivable from this study is that increase in government expenditure without corresponding increase in revenue will expand the budget deficit and government will have to resort to borrowing which could increase indebtedness to multilateral creditors. To make budget expenditure less driven by revenue availability, government should explore a medium term expenditure framework, so that expenditure can be planned and protected from unstable short term revenue availability.

Therefore, government should discover other sources of revenue especially the non-oil minerals sector, and also reduce the size of huge recurrent expenditure and move towards capital and other investment expenditures. Government should also try as much as possible begins expenditure restructuring that is implementable and result- oriented through effective budget packaging and not legislative paddling. Federal Government should also as a matter of urgency help to set targets for revenue mobilization and utilization as well as device a way of expenditure spreading over the entire economy. The study also suggests that Nigeria could improve on the effectiveness of their fiscal policy by making budget expenditure less driven by only one source of revenue(oil) and also explore a medium term expenditure framework, so that expenditure can be planned and effectively protected from unstable short term revenue availability.

\section{References}

Akaike, H., 1969. Fitting autoregressive models for prediction. Annals of the Institute of Statistical Mathematics, 21(1): 243-247.View at Google Scholar | View at Publisher

Al-Qudair, K.A., 2005. The relationship between government expenditure and revenue in the Kingdom of Saudi Arabia: Testing for cointegration and causality.Journal of King Abdul Aziz University: Islamic Economics, 19(1): 31-43. View at Google Scholar | View at Publisher

Al-Zeaud, H.A., 2015. The causal relationship between government revenue and expenditure in Jordan. Internatioinal Journal of Management and Business Research, 5(2): 117-127.

Ali, R. and M. Shah, 2012. The causal relationship between government expenditure and revenue in Pakistan. Interdisciplinary Journal of Contemporary Research in Business, 3(12): 323-329. View at Google Scholar

Anderson, W., M.S. Wallace and J.T. Warner, 1986. Government spending and taxation: What causes what? Southern Economic Journal, 52(3): 630-639. View at Google Scholar | View at Publisher

Aregbeyen, O. and M.I. Taofik, 2012. Testing the revenue and expenditure nexus in Nigeria: An application of the bound test approach. European Journal of Social Sciences, 27(3): 374-380. View at Google Scholar

Baghestani, H. and R. McNown, 1994. Do revenues or expenditures respond to budgetary disequilibria? Southern Economic Journal, 61(2): 311-322.View at Google Scholar | View at Publisher

Barro, R., 1974. Are government bonds net worth? Journal of Political Economy, 82(6): 1095-1 117. View at Google Scholar | View at Publisher

Blackley, P., 1986. Causality between revenues and expenditures and the size of the federalbudget. Public Finance Quarterly, 14(2): 139156. View at Google Scholar | View at Publisher 
Buchanan, J. and R.W. Wagner, 1978. Dialogues concerning fiscal religion. Journal of Monetary Economics, 4(3): 627-636.View at Google Scholar | View at Publisher

Buchanan, J.M. and R.W. Wagner, 1977. Democracy in deficit. New York: AcademicPress.

CBN, 2015. Statistical Bulletin, December, Economic Research and Policy Department, Economic Time Series Database, 26. Retrieved from http://statistics.cbn.gov.ng/cbn-onlinestats.

Central Bank of Nigeria, 2015. Annual report. Retrieved from https://www.cbn.gov.ng/documents/cbnannualreports.asp.

Chang, T., W.R. Liu and S.B. Caudill, 2002. Tax -and - spend, spend - and - tax, or fiscal synchronization: New evidence for ten countries. Applied Economics, 34(12): 1553-1561. View at Google Scholar | View at Publisher

Craigwell, R.C., H. Leon and C. Mascoll, 1994. Government revenue and expenditure causality in the presence of seasonality in Barbados Social and Economic Studies, 43(4): 197-2 18. View at Google Scholar

Darrat, A.F., 1998. Tax and spend, or spend and tax? An inquiry into the Turkish budgetary process. Southern Economic Journal, 64(4): 940-956. View at Google Scholar | View at Publisher

Dickey, D.A. and W.A. Fuller, 1979. Distribution of the estimators for autoregressive time series with a unit root. Journal of the American Statistical Association, 74(366): 427-431. View at Google Scholar | View at Publisher

Dickey, D.A. and W.A. Fuller, 1981. Likelihood ratio statistics for autoregressive time series with a unit root. Econometrica, 49(4): 10571072.View at Google Scholar | View at Publisher

Drummond, P., W. Daal, N. Srivastava and L.E. Oliveira, 2012. Mobilizing revenue in Sub-Saharan Africa: Empirical norms and key detereminants. IMF Working Paper No. WP/12/108. Retrieved from https://www.imf.org/external/pubs/ft/wp/2012/wp12108.pdf [Accessed 15-02-2015].

Emelogu, C.O. and M.O. Uche, 2010. An examination of the relationship between government revenue and government expenditure in Nigeria: Co-integration and causality approach. Central Bank of Nigeria Economic and Financial Review, 48(2): 35-57.

Engle, R.F. and C.W.J. Granger, 1987. Co-integration and error-correction: Representation, estimation and testing. Econometrica, 55(2): 251-276. View at Google Scholar | View at Publisher

Fakile, A.S., F.F. Adegbie and O.S. Faboyede, 2014. Mobilizing domestic revenue for sustainable development in Africa. European Journal of Accounting, Auditing and Finance Research, 2(2): 91-108. View at Google Scholar

Fasano, U. and Q. Wang, 2002. Testing the relationship between government spending and revenue: Evidence from GCC countries. International Monitary Fund Working Paper, No. E62 H50 N15.

Friedman, M., 1978. The limitations of tax limitation. Policy Review, 5: 7. View at Google Scholar

Granger, C.W., 1988. Some recent development in a concept of causality. Journal of Econometrics, 39(1-2): 199-211. View at Google Scholar | View at

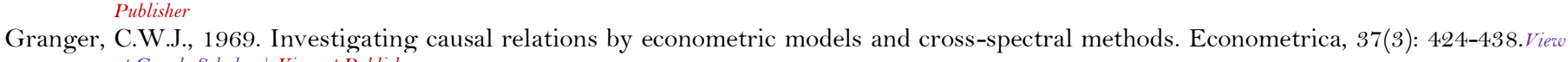
at Google Scholar | View at Publisher

Granger, C.W.J. and P. Newbold, 1974. Spurious regression in econometrics. Journal of Econometrics, 2(2): 111-120.View at Google Scholar

Hasan, M. and I. Lincoln, 1997. Tax then spend or spend then tax? Experience in the U.K.,1961-93. Applied Economics Letters, 4(4): 237239. View at Google Scholar | View at Publisher

Islam, A.M., 2001. Wagner's law revisited: Cointegration and exogeneity Tests for the USA. Applied Economics Letters, 8(8): 509-515.View at Google Scholar | View at Publisher

Johansen, S., 1988. Statistical analysis of cointegration vectors. Journal of Economics,Dynamics and Control, 12(2-3): 231-254.View at Google Scholar | View at Publisher

Johansen, S. and K. Juselius, 1990. Maximum likelihood estimation and interference on cointegration with application to the demand for money. Oxford Bulletin of Economics and Statistics, 52(2): 169-2 10.View at Google Scholar | View at Publisher

Keynes, J.M., 1936. The general theory of employment, interest and money. New York: Harcourt Brace Jovanovich, Inc.

Kollias, C. and S. Makrydakis, 2000. Tax and spend or spend and tax? Empirical evidence from Greece, Spain, Portugal and Ireland. Applied Economics, 32(5): 533-546. View at Google Scholar | View at Publisher

Li, X., 2001. Government revenue, government expenditure, and temporal causality: Evidence from China. Applied Economics, 33(4): 485497. View at Google Scholar | View at Publisher

Mainoma, M.A. and S.A.S. Aruwa, 2015. Public expenditure and revenue: The Nigerian case in managing public finance for development. Kaduna, Nigeria: Fecility Publishers.

Meltzer, H. and S.F. Richard, 1981. A rational theory of the size of the government. Journal of Political Economy, 89(5): 914-927.View at Google Scholar $\mid$ View at Publisher

Miller, S. and F.S. Russek, 1990. Cointegration and error-correction models: The temporal causality between government taxes and spending. Southern Economic Journal, 57(1): 22 1-229. View at Google Scholar | View at Publisher

Mohsen, M. and R.A. Abbas, 2014. The relationship between government revenue and government expenditure in Iran. International Journal of Academic Research in Business and Social Science, 4(3): 17 1. View at Google Scholar

Mohsen, M., P. Mosayeb and E. Yousef, 2011. Government revenue and government expenditure nexus in Asian countries: Panel cointegration and causality. International Journal of Business and Social Science, 2(7): 199-207.View at Google Scholar

Musgrave, R., 1966. Principles of budget determination. In public finance: Selected readings, Edited by H. Cameron and W. Henderson. New York: Random House.

Narayan, P.K. and S. Narayan, 2006. Government revenue and government expenditure nexus: Evidence from developing countries. Applied Economics, 38(3): 285-291. View at Google Scholar | View at Publisher

Nwogwugwu, N. and P.N. Okoronkwo, 2015. Effective revenue mobilization and sustainable development in Lagos asatate, Nigeria. IOSR Journal of Business and Management, 17(5): 15-21. View at Google Scholar

Nwosu, D.C. and H.O. Okafor, 2014. Government revenue and expenditure in Nigeria: A disaggregated analysis. Asian Economic and Financial Review, 4(7): 877-892. View at Google Scholar

Ogujiuba, K. and T.W. Abraham, 2012. Testing the relationship between government revenue and expenditure: Evidence from Nigeria. International Journal of Economics and Finance, 4(11): 172-182. View at Google Scholar $\mid$ View at Publisher

Owoye, O., 1995. The causal relationship between taxes and expenditures in the G7countries: Cointegration and error-correction models. Applied Economics Letters, 2(1): 19-22. View at Google Scholar | View at Publisher

Peacock, A.T. and J. Wiseman, 1961. The growth of public expenditures in the United Kingdom. Princeton, NJ: Princeton University Press.

Peacock, A.T. and J. Wiseman., 1979. Approaches to the analysis of government expenditures growth. Public Finance Quarterly, 7(1): 323. View at Google Scholar

Perron, P., 1989. The great crash, the oil price shock, and the unit root hypothesis. Econometrica, 57(6): 1361-1401.View at Google Scholar | View at Publisher Phillips, P.C.B. and P. Perron, 1988. Testing for a unit root in time series regression. Biometrika, 75(2): 335-346. View at Google Scholar | View at
Publisher

Ram, R., 1988. Additional evidence on causality between government revenue and government expenditure. Southern Economic Journal, 54(3): 763-769. View at Google Scholar | View at Publisher

Saeed, K.P. and S. Somaye, 2012. Relationship between government spending and revenue: Evidence from oil exporting countries. International Journal of Economics and Management Engineering, 2(2): 33-35. View at Google Scholar

Toda, H.Y. and T. Yamamoto, 1995. Statistical inferences in vector autoregressions with possibly integrated processes. Journal of Econometrics, 66(1-2): 225-250. View at Google Scholar | View at Publisher

Von Furstenberg, G.M., R.J. Green and J.H. Jeong, 1986. Tax and spend, or spend and tax? Review of Economics and Statistics, 68(2): 179188. View at Google Scholar $\mid$ View at Publisher

Wagner, A., 1890. Finanzwissenchaft. Leipzig: Winter, C.F. 